\title{
FORUM
}

\section{An Empire For Our Times? A Discussion of Peter Wilson's The Holy Roman Empire: A Thousand Years of Europe's History}

Peter Wilson's remarkable new book, The Holy Roman Empire: A Thousand Years of Europe's History (London: Allen Lane, 2016), highlights the lasting importance of an often poorly understood European entity. Central European History invited four esteemed historians to contribute to a forum designed to offer varied perspectives on this work. Barbara Stollberg-Rilinger (Westfälische WilhelmsUniversität, Münster), Jason Coy (College of Charleston), Len Scales (Durham University), and Tom Scott (University of St. Andrews) agreed to take part. Each participant prepared an initial statement on the book, and, in a second phase, each had the opportunity to read the others' remarks and respond. Finally, Peter Wilson (All Souls College, University of Oxford) graciously agreed to offer his comments on the forum as a whole. We are excited to offer readers a varied and lively discussion that reminds us why the Holy Roman Empire mattered in the past, and how its history remains relevant to our own era.

Julia Torrie

Review Editor

\section{Initial Statements}

Jason Coy (College of Charleston)

I $\mathrm{N}$ the two centuries since its dissolution in 1806, the Holy Roman Empire has usually been viewed as an antiquated relic of the medieval past, a dysfunctional polity that hindered Germany's development into a modern, liberal nation-state. In the wake of its demise, a chorus of famous intellectuals and statesmen-including Voltaire, James Madison, Johann Wolfgang von Goethe, Leopold von Ranke, and Heinrich von Treitschke-derided the Empire as a "monstrosity" hampered by outmoded institutions and backward policies. More recently, in the wake of World War II and the Holocaust, advocates of the so-called Sonderweg thesis blamed the Empire for Germany's belated unification and for the Germans' supposedly "authoritarian" bent. In Heart of Europe [the American title of the study-Ed.], a bold and sweeping account of the Holy Roman Empire's thousand-year history, Peter Wilson sets out to supplant these anachronistic interpretations by explaining "what it was, how it worked, why it mattered, and its legacy for today" (5). With this important book, the best single-volume history of the Holy Roman Empire currently available, Wilson succeeds in answering these fundamental questions and provides fascinating insights into European politics from the early Middle Ages to the present. I would like to focus first on what I see as Wilson's most significant contributions to the existing scholarship on the Empire, and then examine how he treats the Protestant Reformation as a case study of the merits (and drawbacks) of his approach. 
In line with recent positive reappraisals of the Empire, Wilson argues that it provided an effective framework for balancing central authority and regional autonomy, for protecting corporate liberties, and for mediating disputes among princes. Refusing to consider the Empire as a precursor - or as an obstacle — to a unified Germany, he exposes the anachronism inherent in the Rankean portrayal of its history as a tale of failed nation-building. At the same time, however, he is equally opposed to recent suggestions that the Holy Roman Empire prefigured contemporary forms of European integration. Eschewing these two opposing positions, which seek to cast the Empire as an abortive nation-state or as a model for modern transnational polities, Wilson instead seeks to understand the Holy Roman Empire in its own right, within its own historical context.

Wilson boldly eschews the straight chronological approach that has daunted previous historians seeking to tell the story of an empire that lasted for a thousand years and spanned much of the continent. Providing a cultural rather than a political history, he focuses on a series of themes- "ideal," "belonging," "governance," and "society"-examining each of them from the time of Charlemagne until the age of Napoleon. This approach allows Wilson to avoid the "one damn thing after another" tedium that plagues extended historical narrative, and it allows him to focus his analysis on broad historical developments rather than on the course of historical events.

Wilson argues that the decentralized nature of authority in the Holy Roman Empiresupposedly its fatal flaw, according to most scholars—was actually the key to its durability and its greatest strength. He contends that the Empire was established for a specific mission, a mission that did not entail exercising sovereignty in the modern sense. Explaining that the emperor was tasked with providing moral leadership and with protecting the Church, Wilson argues that he was never expected to rule over Christendom. This quasi-religious purpose fostered a distinctive political culture within the Empire, and it helped ensure that imperial governance was always driven by attempts to gain and maintain consensus, not direct rule from the center. This form of governance, maintained largely through processes of negotiation and mediation, allowed regional identities to coexist with imperial institutions and kept the peace in Central Europe for the better part of a millennium. After the Peace of Westphalia brought an end to the Thirty Years' War, German princes preferred to settle disputes in court rather than resort to internecine warfare- even if their territories remained the most heavily militarized in Europe.

Within the Empire, sovereign rulers, both great and small, could set local policies, but their subjects still had recourse to imperial courts for redress. Wilson points out that the Empire did not require its inhabitants to profess exclusive loyalty, as is the case in a modern nation-state; this allowed diverse communities to live within its borders, protected by imperial institutions. As a result, for much of its history the Empire provided a haven for minorities like Jews, who often relied on imperial protection against local persecution. Wilson does not romanticize premodern notions of toleration, however, pointing out that "Jews remained protected provided they accepted their second-class status. Diversity was feared, but also recognized as beneficial” (101).

The Empire's lack of a clear imperial capital and the concomitant development of a multiplicity of princely courts and free imperial cities also fostered technological innovation (including the introduction of the printing press) and cultural achievement. Throughout the Empire, princes competing for status established glittering courts and provided patronage 
for composers, authors, and artists. Small wonder, then, that the Empire's princely courts fostered the talents of luminaries like Wolfgang Amadeus Mozart, Lucas Cranach, and Goethe.

While arguing the benefits of its decentralized political system, Wilson also vigorously refutes the idea that nineteenth- and twentieth-century German authoritarianism originated in the supposed "dysfunction" of the Holy Roman Empire. Scholars have long argued that, within the Empire's "dualist" political system, liberty became associated not with the people, but rather with princes, who oppressed their subjects as they defended their own autonomy in the face of imperial tyranny. By contrast, Wilson argues that the Empire embodied a viable framework of corporate rights, one that made notions of individual equality superfluous. $\mathrm{He}$ argues that liberalism was able to make few inroads in the Empire in the nineteenth century because it threatened these valued corporate rights, not because of authoritarian impulses inherent in the imperial political system.

There has been a push in recent years to "globalize" German history, and one of Wilson's greatest contributions is treating the Holy Roman Empire in its broader regional (and, at times, global) context. He considers the history of the Empire to be a story of European history-no surprise, given that its borders included, at one time or another, parts of eleven modern countries: Austria, Belgium, the Czech Republic, Denmark, France, Germany, Italy, Luxembourg, the Netherlands, Poland, and Switzerland. Refusing to let modern assumptions about the nation-state color his treatment of the Holy Roman Empire, he contends that "the Empire's history is not merely part of numerous distinct national histories, but lies at the heart of the continent's general development" (1). In the course of his analysis, he examines not only the Empire's interaction with states linked to it through dynastic politics, like Hungary and Spain, but also its rivalries with neighboring European powers, like France and Sweden. He does a particularly good job of analyzing the Empire's relations with the Byzantines in medieval times and with the Ottomans during the early modern period. Furthermore, Wilson does not neglect the Empire's connections to Europe's sprawling overseas possessions in the early modern period, something often ignored in the existing scholarship. Citing overseas trading ventures to Russia, Persia, and Dutch Guiana in the seventeenth century, and the establishment of companies to conduct trade with China and India in the eighteenth, Wilson argues that "the absence of a strong, centralized monarchy did not inhibit direct colonial ventures from the Empire" (166).

While he rightfully resists viewing the Empire through the lens of nineteenth-century ideas about nation-states, Wilson provides interesting treatment of the diversity of nationalist sentiments within the Holy Roman Empire. He points out that such sentiments always existed in the Empire, but argues that they fostered multiple and overlapping forms of identity that were not mutually exclusive. Thus, expressions of German, Italian, and Czech cultural identity flourished, alongside forms of regional identity within princely territories like Prussia and Bavaria.

By the fifteenth century, the tension between "the Empire's traditional transnational character and its specific association with Germany" (262) became more acute. The debate over these competing notions of imperial identity intensified after German humanists rediscovered Tacitus's Germania, sparking renewed interest in the idea of a distinct German people. But Wilson is careful not to project nineteenth-century German nationalism onto the imperial past, and he provides an incisive critique of such outmoded scholarship, which was usually based upon fanciful projections into the past of a supposedly essential 
"German" identity. Wilson thus treats the multiplicity of identities within the Holy Roman Empire as a product of its distinctive form of political organization, rather than as a developmental failure or as a deviation from some ideal type. He demonstrates that within the empire, identity was not construed primarily in terms of nationality, but rather in terms of corporate identity, with its inhabitants living as members of a society of orders and belonging to various communities, both real and imagined. Only in the waning days of the Empire, with the emergence of "Romantic nationalism," which called for passionate engagement with the nation as an exclusive linguistic and cultural community, did the traditional multiplicity of identities come into question.

How does Wilson's approach—namely, his focus on the Holy Roman Empire as a whole, rather than as a precursor for a unified German state-affect his treatment of the Reformation, an event usually considered in terms of German history? By viewing the Reformation through the prisms of imperial politics and Habsburg dynastic concerns, he provides an exceptionally lucid explanation of why the religious upheavals of the early modern period proved so difficult for imperial authorities to suppress. Wilson argues that in the pivotal years of 1521-1524, Charles V adhered to the traditional "Two Swords" doctrine, which reserved primacy in issues of dogma for the papacy. He thus viewed the Reformation as a problem of public order, leaving theological issues for the pope to settle through a promised church council. As Charles V focused on stamping out public dissent in this pivotal period - instead of seeking a solution within the empire- the evangelical message spread like wildfire. The Reformation also provides a perfect example for Wilson to demonstrate how the decentralization and flexibility of the Empire's political institutions helped to contain strife among its constituents. He ably shows how longstanding traditions of consensus and negotiation preserved peace in the Empire in an era of religious warfare in Europe, portraying the Thirty Years' War as an aberration in the longer story of religious compromise.

With his focus firmly on the political history of the Holy Roman Empire, the Reformation tends to play a diminished role in Wilson's account. He rightly sets out to correct the excesses of nineteenth-century German nationalist historiography, which placed an outsized importance on the Reformation as a distinctively "German" event and characterized Protestantism as an essentially "German" religion. By contrast, Wilson focuses on how the religious crisis played out throughout the Empire, not only in the German-speaking lands, but also in Bohemia, Burgundy, Italy, and Switzerland.

Wilson refuses to judge the Holy Roman Empire by the standards of nineteenth-century nationalists, no matter how influential their notions of what constitutes a proper nation-state remain. He relies on the recent process of European integration to make his point, positing that "the evolutionary progression once imagined by historians, culminating in a Europe of competing nation states, no longer appears the terminus of political development" (6). Heart of Europe was published early in 2016, shortly before the Brexit vote in the United Kingdom and the election of Donald Trump in the United States exposed the resurgence of nationalist sentiment in the West. Tensions within the European Union (EU) over debt relief and the Syrian refugee crisis, the aggressive stance of Russia in Ukraine and the Baltic region, and rising concerns about the continued viability of the North Atlantic Treaty Organization (NATO) in the twenty-first century, also cast some doubt on his assertions about the imminent demise of nationalist sentiment. Given these recent events, one wonders how Wilson's remarks on the future of nationalism and on contemporary issues of "identity" and 
"belonging" might have changed in light of these developments— and how they might have affected his views on the legacy of the Holy Roman Empire.

\section{Len Scales (Durham University)}

$\mathrm{H}$

Ow to characterize, let alone write the history of, the Holy Roman EmpireSamuel von Pufendorf's monstrous "irregular body," sprawling across Europe's multilingual center as it sprawls across a thousand years of European history? Peter Wilson reminds us of how one eighteenth-century jurist, Johann von Ludewig, consumed 2,500 pages merely in commenting on Charles IV's Golden Bull of 1356. That Wilson himself surveys the Empire's entire history, along with its antique antecedents and modern (and postmodern) echoes, in a little under a thousand pages must therefore rank as a model of conciseness. His book represents a remarkable feat of compressed and ordered erudition, with a thematic and geographic scope fully worthy of its intimidating subject matter. It will be a long time before a scholar emerges who commands the breadth and depth of learning, as well as the inexhaustible stamina, necessary to repeat Wilson's venture for changed times. His book, meanwhile, is presented, in part, as an essay on its own times, and it is the striking contemporary resonances that, alongside its manifest scholarly accomplishments, help explain the lively reception that it has enjoyed since publication. The Holy Roman Empire is back on the agenda.

It perhaps lies in the nature of irregular and monstrous bodies that even the most favorable vantage point will not disclose all their faces in equally sharp relief; yet, Wilson's perspective proves exceptionally fruitful for his task. He is an early modernist, and his is above all an early modernist's Empire: a polity deeply embedded and engrained, with stable (though certainly not immutable) institutions, practices, and ways of thinking and being. His is the Empire memorably evoked by its last Arch-Chancellor, Karl Theodor von Dalberg, as "a permanent Gothic structure that might not conform to all the building regulations, but in which one lives securely" (280). It is an Empire whose inhabitants have, on the whole, arrived at a settled recognition of the need to give and take, reflecting ancestral memories of the terrible consequences of failing to do so. None of this is to imply that Wilson neglects to treat in abounding detail, and with great knowledge and insight, the Empire's medieval centuries, too. But the lens through which he perceives and judges the Empire's history as a whole is an early-modern lens. Wilson's Reich is a well-tempered Reich-one whose emperors inspire distant reverence, more than lurid hopes or fears, from diverse and far-flung subjects who, within their many local worlds, cooperate more than they compete.

The Empire, Wilson is concerned to show above all, was a polity that worked - not all the time, and not without many and varied limitations, but nevertheless more effectively and with more admirable results than successive generations have acknowledged. Particularly after the reforms of the early sixteenth century, taxes were levied, armies were raised, and the peace was kept within the Empire's lands by means not notably less effective than in neighboring, more centralized realms that have traditionally been judged more favorably by scholars. The Empire's endurance for a full millennium, Wilson argues, was no fluke; its historians, in their habitual preoccupation with crises and impending breakdown, have been looking in the wrong places. "Popes and emperors were not necessarily predestined to clash" (47), he insists (although across several medieval centuries, they recurrently and 
spectacularly did so). "Conflict was not always inevitable" (113), even in the Reformation era; there was "no inevitable slide towards war" (124) in the early seventeenth century. Above all, the Empire, with all its flaws, supplied a framework within which, over the course of many centuries, civilized life could and did prosper. The key to this lay in the "inclusive diversity" (262) of the old Reich. It is not without reason that Germany still contains more theaters and opera houses than any equivalent region of Europe. Wilson repeatedly draws favorable comparisons with England-and occasionally makes barbed contrasts with absolutist France. The Empire's forty-five universities in 1800 are juxtaposed with twenty-two French and a mere two English institutions. Reichstag proceedings were the subject of semiofficial record as early as 1501, "well ahead of Hansard," the authorized verbatim account of British parliamentary business. The Empire's first daily newspaper appeared beginning in 1635, sixty-seven years before its English counterpart. Decentralization, moreover, guaranteed relative freedom of speech, "in contrast to France, where 183 people were imprisoned in the Bastille between 1760 and 1789 for breaching censorship laws" (276). As the nobleman George Friedrich von Waldeck asked in the seventeenth century, "Where outside the Empire can one find such freedom as is customary within it?" (283). The question could easily be Wilson's own.

But what if we inspect Pufendorf's "irregular body" from different historical standpoints? One such standpoint might be that of the medievalist, for Wilson's mature Empire, his "common fatherland composed of numerous lesser homelands" (254), had been long in the making. A prophetic treatise, De oneribus prophetarum, produced in Italy at some time after the middle of the thirteenth century, is illustrated with an image of the seven-headed apocalyptic dragon. ${ }^{1}$ Four of the beast's heads are labelled with the names of ancient and medieval (unholy!) Roman emperors, with the largest identified as the recently deceased Frederick II of Hohenstaufen (d. 1250). Across substantial periods of the Empire's earlier history, its rulers inspired sentiments that were neither moderate nor conducive to wellmannered consensus. Recalling the final, embittered years of Frederick II's conflict with the pope and his allies in the Empire's northern Italian towns, the Franciscan friar Salimbene, a native of Parma, wrote that "men could not plough, nor plant, nor reap, nor plant vineyards, nor harvest the grapes, nor even live in villages." 2 Such remarks are not, of course, uncommon in medieval chronicles; but Salimbene's might be taken as illustrative of the effects of what became, in the central Middle Ages, a recurrent pattern of military action by the Empire's rulers in their Italian lands. Often, the armies originated north of the Alps, and were perceived by Italians as barbarous foreign invaders. It was rare for the coronation in Rome of a medieval emperor to pass off without significant clashes between his mostly German troops and the local population.

Such tribulations were too long-lasting to be viewed as a mere unfortunate prelude to happier, more settled times to come. Wilson's concession, that "conquest had played a significant part in ... the early Middle Ages," does not entirely cover the Italian case, where, for many inhabitants, "imperial jurisdiction" never acquired a "benign association with ... a common political order" (232). The greater stability of later centuries was, in part, the result of contraction, i.e., the retreat of imperial rule from fissiparous, yet often important

\footnotetext{
${ }^{1}$ Vatican Library, MS Vat. lat. 3822, fol. 5r.

${ }^{2}$ The Chronicle of Salimbene de Adam, ed. and trans. Joseph L. Baird, Giuseppe Baglivi, and John Robert Kane (Binghampton NY: Center for Medieval and Renaissance Studies, 1986), 181.
} 
territories. If the violent secession of Bohemia in the fifteenth century proved reversible, other withdrawals - of Switzerland, of the Netherlands, of Italy itself-were more lasting. Wilson argues strongly against "the standard fragmentation narrative" (184), familiar from pessimistic, nationalistic visions of the Empire's history of nineteenth- and early twentiethcentury German provenance. If "fragmentation" is understood as code for cultural decadence and incipient political extinction, then clearly he is right. Yet, there were elements fundamental to the character of the medieval Empire-beyond merely the facts of its vast extent and lack of a natural center-that were potent generators of discord.

A glance at the map of pre-modern Europe is enough to make plain that the zones of most intricate local political subdivision were to be found in western and southern Germany and, in imperial Italy, north of Rome. The explanation for this pattern is admittedly complex, and it lies partly with the economic vibrancy, high population densities, and precocious urbanization of the regions in question. But it also has much to do with the rivalries of emperors and popes in these territories, and with the readiness of both parties to trade liberties for the allegiance of key actors and communities at crucial moments in their protracted struggles. Nothing, it seems, entrenched localism quite like the proximity of Christendom's theoretically all-commanding Two Powers. The paradoxical relationship between universalizing ideological projects and fragmenting political landscapes (past and present) is one to which I shall return. The innumerable leagues of towns and nobles that were so characteristic of such landscapes in the Middle Ages were natural, accustomed formations, and they represented a crucial means of survival in circumstances of long-running division and periodically intense conflict. They were more than mere stopgaps, in lieu of an eventual, healthier "growth of ... imperial institutions," offering "more attractive means to maintain their members' identity and autonomy" (568).

The optimistic early-modern template for reading the Empire, when projected backward, fits some aspects of the medieval scene better than others. It may be that Adolf of Nassau-the Cologne archiepiscopal vassal whose short, impoverished reign as Roman king (1292-1298) began with massive concessions to his electors and ended with his deposition by those same princes—was indeed "surprisingly successful" (387); but identifying the elements of that success would require close and sympathetic scrutiny. The "relative strength" that Wilson diagnoses in the post-Hohenstaufen imperial monarchy mostly eluded imperialist treatise-writers of the time. If the Rhine was a "medieval expressway" rather than a "frontier" (183), it was a somewhat constricted one, with more than thirty toll stations along its course already by the end of the thirteenth century. (Only "the raging madness of the Teutons" could explain such "extortions," fumed one English traveller. ${ }^{3}$ ) It could be a frontier, too, at times: alternative routes south, if the river was in flood at Duisburg, were part of the advice offered by the thirteenth-century Franciscan Albert of Stade to German pilgrims heading for Rome. ${ }^{4}$

Underlying Wilson's positive reevaluation of the Holy Roman Empire is another proposed revision, which, so to speak, brings his book up to the minute. For, in unfolding his vision of a robust, functioning political order that defied the rigid categories of sovereign state and nation, he is also implicitly_and, in his closing pages, explicitly—reassessing the

\footnotetext{
${ }^{3}$ Thomas Wykes, writing in the thirteenth century, quoted in Len Scales, The Shaping of German Identity: Authority and Crisis, 1245-1414 (Cambridge: Cambridge University Press, 2012), 68.

${ }^{4}$ Cited in Scales, ibid., 105.
} 
potentialities of a contemporary institution of seemingly comparable character, namely, the EU. Superficial resemblances seem clear enough. Some readers might visualize the European parliamentarians, on their accustomed monthly trundle across the plains of latter-day Carolingia, moving between the assembly sites and dining halls of Brussels and Strasbourg, as if between rich Frankish manors. Others, observing the ritualized, public performance of amity with which fractious EU negotiations habitually conclude, might be put in mind of Gerd Althoff's studies of the political culture of the Ottonian and Salian Reich. ${ }^{5}$ Wilson's point, however, goes deeper: he thus contrasts the "essentialist definitions of identity" (290) that arose in Europe following the Empire's fall, and the modern evils that these spawned, with "the Empire's ability to accommodate different identities within a common framework" (292). Such accommodations appear no less needful today. Now just as then, he proposes, "decentralized structures can spread authority, creating multiple, more local and thereby perhaps more meaningful arenas for decisions to be reached" (686).

Wilson's model may yet prevail. But, as Jason Coy notes, much has happened in the short interval since the book appeared, some of it seemingly inviting fresh viewpoints on Europe's contemporary Pufendorfian "irregular body." If "the evolutionary progression once imagined by historians, culminating in a Europe of competing nation states, no longer appears the terminus of developments" (6), then neither, in its current form at least, does the EU necessarily. In order for the political norms that held together the Empire to play a role in Europe's postmodern future, as they did in its pre-modern past, Wilson acknowledges, "participants must accept that politics can no longer be guided by absolutes" (686). Yet, absolutes seem currently to be exerting as disconcertingly powerful a hold on some sections of the European voting public as they once did on the mind and utterances of a Frederick II or an Innocent IV. We must wait and see whether consensus, compromise, and negotiated solutions, as embedded over long centuries in the Empire, do, in fact, represent a deep-rooted default mode of politics—one to which Europeans will quickly return.

\section{Barbara Stollberg-Rilinger (Westfälische Wilhelms-Universität Münster)}

$\mathrm{F}$ OR at least two reasons, the task of writing a history of "the Holy Roman Empire" from 800 to 1806 is a considerable challenge. First, it requires profound knowledge of a thousand years of history and four centuries of historical scholarship - something that Peter Wilson possesses to a stupendous and admirable degree. Second, it is a challenge because one can doubt if there really was such a thing as "the Empire" as a constant historical subject over that entire time period.

Peter Wilson's fundamental concern is to write a new political, social, and constitutional history of Europe's core region that takes leave from the traditional nation-state narrativessuch as those of Germany, Czechoslovakia, the Netherlands, or Italy. His great achievement is to dismiss anachronistic views and replace them with a broader picture that is much more complex-but also much less clear. Instead of tracing the various national histories back into the medieval past, he writes the history of a strange, multilayered, ambiguous, changing entity called "the Empire," which is a political being sui generis. It was the predecessor of neither the German nation-state nor the European Union and should therefore not be used "to

\footnotetext{
${ }^{5}$ Gerd Althoff, Die Macht der Rituale: Symbolik und Herrschaft im Mittelalter (Darmstadt: WBG, 2003).
} 
articulate present-day agendas" (681). By avoiding such anachronisms, the book represents the most recent state of the art in the field, and I absolutely share this basic premise. The approach nevertheless raises two problems: a problem of presentation and a problem of substance.

The new story is not easy to tell, and Wilson's book is a challenge to the reader. So many political entities, so many identities, so many interpretations, so many changes over time-it is difficult to keep track. This is even more so the case because the author has chosen a nonchronological organization that tears apart the relevant contexts. To give some examples: If one wants to know how Bohemia developed and was related to the Empire throughout the centuries, one has to piece together disparate passages located in various places in the book. The same holds true if one wants to understand how decision-making worked (or was avoided) over time, how imperial assemblies changed their character over the centuries, which role the electors played in the unity of the Empire, etc. To understand these complicated constitutional structures, i.e., to find out what made the Empire a political body-its practices, procedures, discourses, laws, contracts, rituals, offices, insignia, places, etc.- one needs to know about their respective development over time. For each of these topics, the book offers incredibly rich material, but the reader has to find his or her own way through the thicket (without receiving much help from the somewhat terse table of contents). The chronological overview at the end of the book is helpful but not sufficient.

The problem of form is related to a problem of substance. Wilson's most important criticism of the national narratives is that they all "work by projecting later developments deep into the past" (256), thus construing false continuities. In trying to avoid these nationalistic biases, however, he sometimes falls into a similar trap by projecting a political entity called "the Empire" back into the ninth century. Learned contemporaries of the eighteenth century would have denied that they were still living in the same Empire that Charlemagne had. For Johann Stephan Pütter, for example, one of the most reputable specialists of the imperial constitution, the medieval idea of the Holy Roman Empire was a mere fantasy, a delusion that hardly needed any confutation ("ein Wahn, der jetzt kaum noch einer Widerlegung bedarf ...")-though it had had severe historical consequences. ${ }^{6}$

The decision to write the history of "the" Empire from Charlemagne to Francis II introduces this problem into the very task that Peter Wilson sets for himself: by invoking the unity of the Empire in his title, he cannot help but insinuate that the Empire was a consistent political entity over the centuries. Wilson is not always clear about this crucial question. On the one hand, he is well aware that there was not a single element of uninterrupted continuity from 800 to 1806: no single territory, boundary, ethnos, dynasty, crown, place, or language. Even the imperial title migrated from West to East and the word imperium changed its meaning profoundly over time. On the other hand, Wilson uses metaphors that depict the Empire as a consistent political body with a "birth," a "life," a "lifespan," with the capacity to act, speak, handle conflict, etc. This is not a mere manner of speaking: it is a misleading supposition that contradicts the author's own insights. In fact, there was no continuity of "the Empire" as a real body politic, but rather a series of retrospective fictions of continuity. To write the history of "the Empire" as a political unity means to reproduce a myth — the late medieval myth manifested in Albrecht Dürer's portrait of Charlemagne from 1510.

${ }^{6}$ Johann Stephan Pütter, Litteratur des Teutschen Staatsrechts, vol. I (Göttingen: Vandenhoek, 1776), 35. 
In the first chapter, Wilson speaks about the "foundation" of the Empire in 800. What really happened in 800 , however, did not resemble any kind of founding act at all. As he correctly describes in full detail, there was just a request for help by Pope Leo III, which allowed Charlemagne to insert himself into the ancient Roman tradition-while, at the same time, fiercely emphasizing his own independent, Frankish reign as the foundation of his power. No political body was founded at all, then, in the year 800 . The act of 800 was not interpreted as an act of translatio imperii before the eleventh century. Only then did historians begin to count the line of emperors, without interruption, from Augustus to their own present. Second, there was a clear break of continuity between the reign of Charlemagne and that of the Ottonians. During the intervening decades, the imperial title had become an object of local conflicts between leading families in the city of Rome. When Pope John XII offered it to the East Frankish king Otto in 962, he established an entirely new tradition. Again, it was not before the thirteenth century that the cult of Saint Charles and his holy insignia took shape and was transformed into an imperial treasure dating back to the ninth century. And it was not before the end of the fifteenth century that a new constitutional framework of institutions and procedures developed which made "the Empire" a political body that could act collectively - in particular, against the emperors from the powerful house of Habsburg whose own territories were excluded from most of the new institutions: in short, Reich versus Kaiser. As Peter Wilson makes very clear, around 1500 the new institutions formed the smaller "Empire of the German Nation," which must be distinguished from the wider Empire that still included more peripheral provinces like Bohemia, the Habsburg Netherlands, the Italian feudal lands, etc.

What was called "the Empire," then, was, something completely different at different times. And, to make things even more complicated: there existed at any time completely different interpretations about what "the Empire" really was, depending on different legal criteria and political claims. Its institutions were highly ambiguous since nobody-including the emperor-had the final say with regard to how to interpret the imperial constitution. It is even doubtful if there was something like a constitution at all. Wilson emphasizes what the Empire was not: there was no formal organization, no clearly defined territory, no direct rule over the population. One could even deny that there were imperial subjects, in the narrow sense of the term. Strictly speaking, the Empire was not even an empire, at least not in the sense of imperialist theories dating from the nineteenth and twentieth centuries. There were innumerable competing claims by various political actors, while conflicts characteristically remained unsettled over decades, if not centuries. We cannot define what the Empire "really was," then: we can only describe what was meant by "the Empire," how various procedures and rituals worked (or did not work), and how all this was perceived and interpreted from different perspectives.

Peter Wilson knows all this better than anyone else, and he demonstrates an astounding familiarity with all branches of the relevant research - the medieval, as well as the early modern, periods. But whoever takes the risk of writing the history of this monstrous, mythical thing called "the Empire" risks writing a book that is as puzzling as its subject. In fact, Wilson's book is a masterly puzzle that requires a careful and attentive reader prepared to gather together its many pieces as he or she sees fit. The reader's patience is rewarded, however, with enormously rich material and a thousand fascinating insights. 


\section{Tom Scott (University of St. Andrews)}

$\mathrm{T}$ HERE is a certain piquancy in the fact that Peter Wilson's Heart of Europe (its American title) appeared two years after André Holenstein's Mitten in Europa, a trenchant essay in revisionism which argued that Switzerland was not as exceptional a polity as venerable national historiography believed. ${ }^{7}$ Indeed, Holenstein's pointed conclusion is that many of the problems facing what Ascanio Marso called in the mid-sixteenth century the "league of discordant members" apply just as much to the present European Union, beset by internal and external difficulties. In his concluding chapter, "Afterlife," Peter Wilson also considers the Holy Roman Empire as a "European project" avant la lettre, which, though fraught with "multiple paths, detours and dead ends" (6), nevertheless not only survived over an astonishing span of time, but also gradually evolved quite sophisticated means of what nowadays would be called conflict resolution.

The foundations of that achievement must surely lie in the later Middle Ages, and it is upon those centuries that the following remarks concentrate. They are intended as reflections prompted by Heart of Europe and other related studies, rather than as a detailed critique. Wilson does not slavishly follow any of the available interpretations of the Empire's development around 1500, but he is broadly sympathetic to Peter Moraw's concept of gestaltete Verdichtung (shaped or planned consolidation) manifest in institutional advances - though he redresses the imbalance in Moraw's account by devoting as much space to regions "distant from the crown," especially northern Germany, as he does to those "near to the crown" (mostly in the south). ${ }^{8} \mathrm{He}$ also advocates a more gradualist approach to "consolidation" than Moraw does. That is all the more justified since Tom Brady has convincingly demonstrated that discourse over imperial reform stretched well back into the fourteenth century. ${ }^{9}$ Yet, there are aspects of the age to which a socio-political approach does not do full justice. The Empire's role as a salvific community (almost a community of fate, or Schicksalsgemeinschaft) deserves greater attention than it receives from Wilson: there is more to the contrast between monarchies and empires than merely constitutional differences. Apart from the obvious fact that three of the Empire's electors were prince-archbishoprics, with other bishoprics and ecclesiastical foundations exerting political and religious influence in their own areas, two major councils of the church took place on German soil at the beginning of the fifteenth century - a deliberate strategy on the part of Emperor Sigismund (r. 1410-1437); moreover, five crusades against the Bohemian Hussites were launched from German soil during that century (though with international participation). Humiliatingly unsuccessful they may have been, but the fact that they were mounted at all is a remarkable testimony to the continuing ideological force of the translatio imperii that Wilson stresses for earlier centuries but plays down here. In part, the Empire's salvific mission was undergirded by the German humanists' retrieval of a heroic German antiquity that invigorated public

\footnotetext{
${ }^{7}$ André Holenstein, Mitten in Europa. Verflechtung und Abgrenzung in der Schweizer Geschichte (Baden: Hier und Jetzt, 2014).

${ }^{8}$ Peter Moraw, Von offener Verfassung zu gestalteter Verdichtung. Das Reich im späten Mittelalter 1250-1490 (Franfurt/Main: Propyläen, 1989).

${ }^{9}$ See Part II of Thomas A. Brady, Jr., German Histories in the Age of Reformations (Cambridge: Cambridge University Press, 2009).
} 
discourse over the function and valency of what came to be known at the time as the Holy Roman Empire of the German Nation.

Any attempt to affirm a growing sense of German national identity in the later Middle Ages nevertheless has its perils; Caspar Hirschi's attempt to construct a German "community of honor" around 1500 needs to be treated with caution. ${ }^{10}$ It is true that the distinction between tútsch and welsch was becoming sharper, not least as a result of the Burgundian Wars (1474-1477), with French-speaking lands within the Empire gradually drifting away from its Germanic core. But that ignores a much more significant reorientation within the Empire, namely, the perceptible estrangement between southern Germans ("Swabians") and the Swiss, where the alienation was not linguistic but political and cultural. Although it is well recognized that the Swiss retained much loyalty toward the Empire as an ideal and as an overarching carapace (Dachverband) that transcended territorial conflicts, the Helvetic Confederation saw itself as an increasingly distinctive and independent polity. That perception derived not so much from the stereotype of a sturdy Alpine free peasantry or from an allegiance to republican and communal values (both topoi now effectively demolished by recent scholarship), but rather because the Swiss cantons were able to breathe new life into the medieval framework of leagues and associations that had earlier informed the Empire itself. That allowed the Swiss_admittedly, after considerable struggle (above all, during the Old Zurich War of 1436-1450) — to accommodate differences, even if the religious divisions of the early sixteenth century in the Kappel Wars (1529-1531) brought the Confederation to the brink of disintegration. Through a flexible and very specific form of alliances (known as Burgrechte), the Swiss succeeded in erecting a polity that might well have confirmed Hendrik Spruyt's belief that leagues and associations offered a viable alternative to the sovereign state- - had Spruyt bothered to include Switzerland in his analysis. In fact, Spruyt concludes somewhat lamely that both leagues and city-states were ultimately dead ends. ${ }^{11}$ It would be interesting to know whether Peter Wilson counts them as one of his "dead ends," and, if so, why, for he barely mentions Spruyt. The Swabian League (1488-1534) was a reasonably successful, regional peace-keeping force, but it never acquired an institutional cohesiveness capable of overcoming sectional and Estatal interests. Indeed, a more detailed discussion of the place of leagues within the imperial framework would have been welcome in Wilson's study: Moraw sees them as essentially steered by the princes, an approach confirmed by Horst Carl's study of the Swabian League or Gabriele HaugMoritz's work on the Schmalkaldic League.

In any event, Switzerland did anticipate subsequent events in the Empire in one respect, inasmuch as the Second Peace of Kappel may be seen as foreshadowing en miniature the Religious Peace of Augsburg a generation later. Yet, the real significance of Switzerland's detachment from the day-to-day business of the Empire was that it showed how far the Empire had travelled from its medieval configuration as a polity bound together by feudal and personal bonds, to an association of principalities under territorialized lordship (Landesherrschaft); in it, the emperor, far from being a mere figurehead, could act through imperial institutions, such as the imperial circles (Reichskreise), as arbiter and umpire to

\footnotetext{
${ }^{10}$ Caspar Hirschi, Wettkampf der Nationen. Konstruktionen einer deutschen Ehrgemeinschaft an der Wende vom Mittelalter zur Neuzeit (Göttingen: Wallstein, 2005).

${ }^{11}$ Hendrik Spruyt, The Sovereign State and its Competitors: An Analysis of Systems Change (Princeton, NJ: Princeton University Press, 1994).
} 
resolve or defuse competing territorial interests. One key to success lay in the almost uninterrupted rule of the Habsburgs, which not only provided symbolic continuity but also shifted many of the burdens of the Empire (military and fiscal) onto the Habsburg patrimonial lands. The importance of this safety valve has sometimes been underestimated. Peter Wilson is alert to all these aspects, without feeling the need to ascribe to the Empire qualities of nationhood or statehood that it manifestly did not possess.

Throughout Heart of Europe, Peter Wilson is keen to ignore (or dismiss) supposed turning points in imperial affairs. For the period from 1350 to 1600, this results in brief treatment of the Reformation, which strikes me as entirely justified if the focus is fixed steadfastly on the Empire as a composite polity: the Reformation surely heightened its variegation and demonstrated its resilience. The worldwide consequences of the Reformation are a separate issue. But there is one aspect of this period which, at first sight, may seem irrelevant to a political account but which may, in fact, help to explain why religious and confessional conflict never had the dire consequences that befell France or England: by 1500 the German lands were fast becoming an economic backwater. Competition for control of resources and trade routes lost much of its edge. That point has partly been obscured by the rise of the Spanish Habsburg Empire with its vast mineral riches in the New World, which only hastened the decline of German mining companies and banking houses. The shift of the European economy from the Mediterranean to the Atlantic has too often been adduced as a catch-all explanation; Heinz Schilling has usefully reminded us that economic activity in the Baltic remained quite vigorous. ${ }^{12}$ Nevertheless, the nations that dominated early modern Europe-France, England, and the Dutch Republic-did so because they were locked in a struggle for ascendancy within a new mercantile-maritime economy.

The decline of the German economy naturally displayed huge regional variations. But the Hansa League was largely a spent force by 1550; the extractive industries of the eastern borderlands were producing much less silver and copper, while the southern German trading companies had either gone bankrupt or were transforming themselves into agrarian rentiers (or occasionally entrepreneurs). Few German cities (except Hamburg) grew appreciably in size during the period; there was little immigration of skilled workers bringing new trades and techniques. In short, by the later sixteenth century, the German lands of the Empire had lapsed economically into placid inertia (and the same held true for the once vigorous Italian city-states). It is hard to believe that this process had no political consequences. The manifestations of commercial and financial crisis were debated at imperial diets throughout the sixteenth century - not least the question of monopolies and imperial coinage reform, a topic that Wilson more or less skirts; many of these issues had already exercised Martin Luther and can be traced back to the fifteenth century. ${ }^{13}$

Wilson is nevertheless to be congratulated on steering a steady course between rival interpretations of the nature of the Reich itself - and on not getting bogged down in ancient and modern controversies: Otto Brunner's Land und Herrschaft, or Peter Blickle's communalism

\footnotetext{
${ }^{12}$ Heinz Schilling, Martin Luther. Rebell in einer Zeit des Umbruchs. Eine Biographie, 2nd rev. ed. (Munich: C. H. Beck, 2013), 23-55.

${ }^{13}$ See Philipp Robinson Rössner, Deflation-Devaluation-Rebellion. Geld im Zeitalter der Reformation (Stuttgart: Franz Steiner, 2012); idem, “Burying Money? Monetary Origins and Afterlives of Luther's Reformation," History of Political Economy 48, no. 2 (2016): 225-63.
} 
thesis, to take two obvious examples. He thereby deprives himself of opportunities to fire linguistic salvoes; at times I would have welcomed a whiff of cordite.

Two cavils: the chronology would have been better placed at the beginning of the book. and a bibliography would have aided negotiation through the vast literature.

\section{Responses}

Jason Coy

$\mathrm{I}$ READ all the other contributors' responses to Heart of Europe with great interest, and they open up exciting new perspectives for considering the book. One thing that was immediately apparent from the responses was a shared recognition of the immense challenge that Peter Wilson took upon himself in attempting such comprehensive treatment of a subject as vast and complex as the history of the Holy Roman Empire across a thousandyear span. By situating Wilson's approach within the broader historiographical context, Tom Scott, in particular, provides a useful way to assess the significance of Wilson's achievement in light of recent work on the Empire, showing how he builds upon the best recent work on the subject. All of the contributors to this forum also applaud Wilson for his skill as a writer, one who challenges readers with the sweeping scope of his subject while delighting them with an abundance of colorful anecdotes and examples.

The contributors also recognize the importance of Wilson's valiant attempt to avoid the anachronism inherent in traditional examinations of the Holy Roman Empire. Much of the scholarship on the Empire has denigrated it as inferior to the nation-state that nationalist intellectuals championed in the nineteenth century. Wilson sets out instead to consider the Empire as a functional polity, arguing that, for most of its history, it promoted stability in Central Europe. Wilson contends that, by fostering "consensus," the Holy Roman Empire successfully mediated between competing regional and ethnic identities and preserved the peace for the better part of a thousand years. While this may be true enough for the period I study, the early modern era, Len Scales offers a striking corrective from the perspective of a medievalist. Scales reminds us that, for medieval Italians, the Holy Roman Emperor was neither a symbol of unifying collective identity nor a guarantor of peace. Rather, during the central Middle Ages, Italians often viewed German emperors campaigning across the Alps as "barbarous foreign invaders" bringing disorder and destruction.

In my initial response to Heart of Europe, I applauded Peter Wilson's non-chronological approach, suggesting that it provides a useful way of treating the Empire's history from a thematic perspective. While Barbara Stollberg-Rilinger agrees that this approach represents the "state of the art" of the field, she also argues that it introduced a troubling problem that undermines the work as a whole. The serious challenge that she presents-one that made me rethink aspects of my own reaction to Wilson's book-is to question whether the Holy Roman Empire even existed as a stable entity that can be examined across the centuries. She argues, quite convincingly, that "we cannot define what the Empire 'really was,' then: we can only describe what was meant by 'the Empire,' how various procedures and rituals worked (or did not work), and how." Thus, in her view, the Empire remained a sort of "imagined community" that was constructed in vastly different ways throughout its long 
history, which means that the distinction between the polity, on the one hand, and, on the other, how it was represented, experienced, and understood is difficult to ignore.

Finally, I was interested to see that Len Scales was also struck by the unfortunate timing of Heart of Europe's publication. Scales similarly suggests that the political events that transpired in the short interval between the book's publication and our forum call into question Peter Wilson's confidence in the durability of the EU. As Scales rightly notes, "We must wait and see whether consensus, compromise, and negotiated solutions, as embedded over long centuries in the Empire, do in fact represent a deep-rooted default mode of politics, to which Europeans will quickly return."

\section{Len Scales}

$\mathrm{T}$

HE four contributions to this forum make clear that Wilson's book is, in more ways than one, a fitting monument to its subject. Pre-modern political discourse on the Empire, as Wilson himself has observed, had the character of "an endless dialogue without a universally accepted conclusion" (277). It may turn out that his book, in its richly nuanced treatment of an endlessly complex series of protracted and shifting histories, permits no greater finality on the part of his readers: the Empire, after all, has long provided, and will doubtless continue to provide, a mirror for succeeding generations of Europeans to inspect their own changing world. Perhaps that is all to the good. In what follows I will therefore offer brief comment on what seem to me three interrelated pieces of unfinished business - possibly destined long to remain that way. These relate to the unity of the Empire's history (and the legitimacy of speaking at all of a single such history), to the Empire's relationship with Germany and the Germans, and to its significance in relation to what came, and continues to come, afterward.

James Bryce, in the last major general history of the Empire written in English, claimed with regard to Francis II's abdication of 1806 (at the time still within living memory) that it had extinguished "the oldest political institution in the world." ${ }^{14}$ Being overimpressed by the Empire's appearance of exceptional historical continuity has a long-in some hands, a dangerous-tradition. Barbara Stollberg-Rilinger is surely right, therefore, to demand a cleareyed awareness of the many and profound discontinuities that lie beneath the seductive myth of a timeless, enduring Reich. And yet, breaches, cataclysms, and fateful wrong turns were very much a part of the Empire's myth, particularly in its toxic German-nationalist incarnation. Wilson's sober, rigorously quantified, (literally) down-to-earth view of a material, irreducibly plural, and localized world appears more as a powerful antidote to the mythologized Reich than as a symptom of its perpetuation. The contrast that Wilson traces-between the multiple, layered, and relativized communities and allegiances characteristic of the Empire's lands, on the one hand, and the centralizing trajectories of the Western monarchies (despite making the latter seem rather more centralized than they actually were), on the other-is defensible. The long view helps here.

Indeed, far from his book nourishing the myth of the Empire, it is arguable that the imperial idea receives a little less than its historical due among Wilson's many local and regional vantage points. In a detailed history of institutions and their workings, the Empire as idea

\footnotetext{
${ }^{14}$ James Viscount Bryce, The Holy Roman Empire, rev. ed. (London: Macmillan, 1928), 1.
} 
is too easily marginalized as mere illusion — and a faintly ridiculous one at that. The gigantic scope of its claims and titles seems only to draw attention to the vast disparity with the putative resources for their attainment. The Empire, as Wilson shows, was a thing conjured up from many reams of parchment and paper. It is tempting here to think of Maximilian I's pop-up-cardboard triumphal arch that could be packed away neatly into a box. But imperial illusions have their own long history and their own importance (as Maximilian well understood, commissioning Albrecht Dürer, among others, to decorate his portable chimera of triumph). There is merit, therefore, in Tom Scott's reminder that an empire-and this one especially-is a peculiar polity that draws on particular funds of cultural capital. Among these was a uniquely potent strain of prophecy: a sacred history of the future. To explain why the image of Barbarossa asleep beneath his mountain cast such a strong mythic spell on bourgeois patriots in nineteenth-century Germany, we must recall the peculiar mix of doctrine and promise that had been woven around the Empire's rulers. Of course, fabricating the Empire of myth, as Stollberg-Rilinger points out, was itself the accumulated work of centuries; but precisely the importance of grasping that truth appears as a powerful case in favor of Wilson's long view. It might even be said that, in changing its shape, its forms, and its character across many centuries - while all the time insisting on legitimizing continuities with a remote past - the Holy Roman Empire proved itself to be the authentic heir to its ancient and late-antique Roman forebears.

Foremost among the dangerous delusions that Wilson has been widely praised for stripping away is that of the directly "German" character of the Reich. ${ }^{15}$ It is necessary only to recall how, after annexing Austria, Adolf Hitler sanctioned the transfer of the medieval imperial insignia from Vienna to Nuremberg for display at the 1938 Reichsparteitag, to see the perils of too ready association of the Empire with German nation- or statehood. Jason Coy therefore properly commends Wilson for "refusing to consider the Empire as a precursor-or an obstacle - to a unified Germany." Yet, due scholarly caution can easily veer into pusillanimity, especially when reinforced by contemporary anxieties and sensitivities. In some branches of the historical profession, particularly in Germany, discussing the genealogy of ideas of Germanness has, for understandable historical reasons, become more than problematic-it has become a form of academic bad manners, to be sidestepped with embarrassed silences and evasions. Wilson, whose history has much to say about varied conceptions of "the Germans" down the ages, is, admittedly, wholly innocent of such a charge. Nevertheless, partly because of the complexity of the topic itself, the reader is likely to end up understanding more about the ways in which the Empire "complicated the definition of German national identity" (255) than about how it may have stimulated it.

The question of the Empire's role in forming past (and more recent) conceptions of a German cultural, political, and territorial community nevertheless remains a valid and potentially important one. Of course, the distorting effects of "modern assumptions about the nation-state" (in Coy's words) must be firmly resisted. Yet, the idea of a special historic relationship between the Empire and the "German people" did not spring Frankenstein'smonster-like from the heads of German-Romantic philologists one dark and stormy night toward the end of the Napoleonic Wars. It went back much further. Across many centuries

\footnotetext{
${ }^{15}$ See, e.g., the reviews by Christopher Kissane in The Guardian (April 1, 2016) and by Tom Holland in The Daily Telegraph (Feb. 22, 2016) — with the latter welcoming Wilson's focus on the Empire's “amorphous, multilingual character."
} 
there developed a rich, if not consistent - let alone standard — vocabulary of terms and concepts associating the Empire with Germany and the Germans. That association became more direct in the Empire's final centuries, when its extent contracted to a core of lands whose inhabitants mostly spoke some form of German. Also venerable is the idea of the Reich as not merely a German polity but as a German problem. Pufendorf's De statu imperii Germanici (1667) is among the more famous of a succession of tracts written between the late Middle Ages and the Empire's end to address the matter. The view that the emperors of the high Middle Ages had recklessly squandered in Italy their chance to strengthen Germany did not have to await the "anachronistic" priorities of nineteenth-century nationalists: it was already to be encountered, for example, in Jakob Carl Spener's Historia Germaniae of 1716. Tracing the roots of such seductively powerful preoccupations remains part of the proper job of the historian.

What, then, if, in the prophetic spirit of imperial political theology, we look forward? It is surely a sign of interesting times when an English historian is moved to take on the daunting task of writing the Empire's history. As noted, the last to do so was Bryce during the high summer of Victorian English imperialism. Bryce's hymn to the imperial ideal went through no fewer than sixty-five editions in Britain and North America by 1958. How Wilson's tract, written for very different times, will be received in the years ahead will be interesting to observe. The contributors to the forum reach divergent views on how far and in what ways his book seeks to bring the Empire into dialogue with the contemporary EU. But there is perhaps a further possibility: that Wilson's praise for the Empire as an order of politics is intended less to flatter the current EU than to stimulate ideas for a future, better one. That would place his book within that most traditionally imperial of genres, the historically-grounded Reformschrift, i.e., a call for renewal drawing on deep erudition about times long past.

\section{Barbara Stollberg-Rilinger}

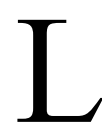

IKE every genuine masterpiece, Heart of Europe can be read in various ways. While all of the participants in the forum are in agreement on their considerable appreciation of Peter Wilson's great book, they all, not surprisingly, highlight different aspects. We all praise the book's thematic breadth and chronological scope. To tell an overarching story of the medieval and early modern Empire is Wilson's greatest achievement-but also the greatest challenge he faced. Not surprisingly either, this is what has, by the same token, also prompted critical remarks from medievalists and early modernists.

Tom Scott, a specialist for the Reformation era, criticizes Wilson for dismissing the turning points around 1500 and for neglecting the subsequent economic decline of the German lands. Len Scales, a medievalist, finds that Wilson reads the medieval Empire through the lens of an early modernist, projecting an "optimistic early-modern template ... backwards" onto the Middle Ages. I agree with Scales, and I would even argue that the early modern Empire was also less stable and peaceful than it might appear from a medievalist's perspective. However, it seems to me that this all-too-harmonious picture is not so much the one presented by Peter Wilson but rather that of Jason Coy. Let me confine my "metacomment" to this fundamental issue. 
At times, it seems as if Coy adopts a somewhat romanticized image of the Empire- which is not the picture Peter Wilson has painted. Wilson abstains from value judgements, instead describing the pre-modern Empire in sober, factual terms. The Empire was no nation-stateit was not even a state. But this is neither a vice nor a virtue, just an empirical fact. Coy's comments, by contrast, present the Empire's long history as a story of harmony and success. According to him, the imperial constitution protected liberties, fostered diversity, provided a haven for the Jews, mediated disputes, favored consensus, and, in this way, was able to keep "the peace in central Europe for the better part of a millennium." From this perspective, the Thirty Years' War was consequently a mere "aberration." But this seems like a difficult argument to sustain. After all, what about the War of Schmalkalden (1546-1547), the Seven Years' War (1756-1763), the various wars of succession between imperial princes-not to mention the medieval feuds or the structural conflicts between pope and emperor highlighted by Len Scales? To avoid the shortcomings of the old nationalistic narrative, one should not make the opposite mistake and celebrate the Empire's constitution as being the better historical alternative to the modern nation-state. This view strikes me as just as anachronistic as the old one.

The question of whether or not "the Empire worked effectively" does not take us very far but instead obscures the complex phenomena with which the book deals. This question implicitly suggests that there was something like an overall program on which the imperial constitution was based. Yet, there was no such thing as a master plan-neither in the Middle Ages nor in the early modern period, nor even in the time of the so-called Reichsreform. Rather, there were cooperative as well as antagonistic actions that had unintended consequences, all of which jointly produced more and more complex political structures. If we call these structures effective or successful, we need to ask: according to which standard, from which perspective, and to whose benefit? Benefits for some obviously involved costs for others. The flip side of consensus was indecision, the flip side of corporate liberty was legal inequality, etc. But in terms of structural analysis, there are good reasons to describe the late eighteenth-century Empire as a dysfunctional political system. At least during its last period, it was unable to defend itself as a political body: it was dissolved by its own members and ceased to exist. Is that not a dysfunctional outcome?

One of the books greatest merits is the fact that Wilson abandons anachronistic standards. Today we should be able to describe the changing structures of the Empire without inappropriate, normative undertones. The picture is neither black nor white, neither positive nor negative, but consists of a hundred shades of grey. This is a historiographical achievement that we should not undermine with attempts to tell an overall positive counternarrative.

\section{Tom Scott}

\footnotetext{
A $s$ the others have noted, all four contributors are either late medievalists or early modernists, and that cannot help but color their remarks. Wilson, too, is an early modernist, and several colleagues have suggested that he takes too benign a view of the medieval Empire, either in its origins or in its practice. Here the perennial problem of language obtrudes. Only Len Scales deploys the term polity, which has gained currency in recent English-language historiography; unfortunately, there is no exact equivalent in any other European language. Yet, in its deliberate neutrality, polity frees us from the shackles
} 
of institutionalism, the putative search for "statehood" or "nationhood"-Barbara StollbergRilinger's contention that the early Empire only acquired visible contours after 1100-and allows us to compare the Empire with other polities of a similar degree of deviation from the "norm," such as Switzerland. Clearly the Empire, unlike the leopard, did change its spots over time, but it would be too easy to be beguiled by Stollberg-Rilinger's seductively elegant characterization of the Empire as lacking any continuity as a real body politic, comprising instead a series of retrospective fictions of continuity, since such constructs could equally well describe the evolution of Switzerland, Scotland, or even France in the Middle Ages.

Scales argues that the medieval Empire was, in its governance, more frequently locked in conflict with other powers - the papacy or secular neighbors - than Wilson allows, though, as Jason Coy observes, such tensions were as often as not engendered by its unique salvific mission as guardian and promoter of Latin Christendom. Yet, loyalty to the Empire as an ideal beyond its shrinking frontiers could be long-lived, as in the imperial cities located on Swiss soil or in eastern Lombardy in the fifteenth century, where Emperor Frederick III was hailed on his several passages (disingenuously, no doubt) as a counterweight to expansionist Venice.

Scales and Coy stress the importance of leagues as organizers and sustainers of public authority at the local level: the essential regional peacekeepers before the ascent of consolidated territorial principalties. These, Scales contends, were prevalent in western and southern Germany (and in northern Italy). But why leagues as a "political principle" ultimately foundered (except in Switzerland) is a problem that neither Wilson nor Scales nor Coy adequately addresses: fleeting references to Hendryk Spruyt's The Sovereign State and Its Competitors overlook the fact that this is a deeply flawed analysis (which does not even mention Switzerland). The early compilation of the Reichstagsakten, instanced by Wilson and endorsed by Scales, as a sign of the Empire's Verdichtung needs to be placed alongside the equally early eidgenössische Abschiede, of which each canton made its own copy (the nineteenth-century edition is a redaction of these individual volumes) — and it would be a brave person to argue that they were a vehicle of Verdichtung: if anything, they were a testimony to stubborn particularism and separatism.

There is general agreement that the Reformation did not mark a turning point in the history of the Empire (as opposed to Latin Christendom), since, in political-constitutional terms, the polity was flexible enough to survive the confessional split. But the matter needs be put more dialectically than either Wilson or Coy suggests. Here Hans Guggisberg's verdict on Switzerland makes the point: namely, that the Reformation there did not achieve its aim "because it succeeded only partially and partially it also failed." 16 In other words, "flexibility" was negative rather than positive, an accident rather than a deliberate political choice. Coy may contend that it was Emperor Charles V's decision to adhere to the doctrine of the Two Swords (i.e., he regarded the issue as a problem of public order rather than of theology) which ensured that the Empire was not blown apart, but this strikes me as an unduly lenient interpretation; surely the power-political stalemate among the princes played a vital role as well.

\footnotetext{
${ }^{16}$ Hans R. Guggisberg, “The problem of 'failure' in the Swiss Reformation: Some preliminary reflections," in Politics and Society in Reformation Europe: Essays for Sir Geoffrey Elton on his Sixty-Fifth Birthday, ed. E. I. Kouri and Tom Scott (Houndmills: Macmillan Press, 1987), 206.
} 
Both Scales and Coy echo Wilson's stress on the Empire's remarkable cultural efflorence in the early modern period (theaters, opera houses, libraries, and universities), which was the result of competitive patronage (or delusions of grandeur) by princes both mighty and duodecimo. But there is no mention of the fiscal extortion or occasional bankruptcies that this search for prestige entailed. Here a dose of Bernt Engelmann's savage tongue-lashing of the supposedly cosy world of the princes would have been welcome. Coy and Scales, by contrast, are in agreement over the threadbare notion of German "liberty"-code for the princes' assertion of independence vis-à-vis the emperor. Coy is rightly willing to talk of the princes' "oppression" of their subjects, but the debate needs to be reframed to avoid the chestnut of the so-called second serfdom east of the Elbe. Forms of servitude remained prevalent in much of Germany west of the Elbe, and, while Heide Wunder's controversial verdict that serfdom (Leibeigenschaft) transformed itself from an instrument of unitary subjection into a badge of uniform citizenship has much merit, restrictions on freedom of movement, marriage, or inheritance continued between, and even within, territories.

The structure of Wilson's book does not make for easy reading (as Stollberg-Rilinger points out): though it is fluently and stylishly written, it deliberately eschews a straightforward narrative. Too bad for the impatient or superficial reader, since Wilson and his commentators all agree that the Empire must be seen through the prism of shifting local and regional identities, which were neither necessarily antagonistic nor mutually exclusive. Still, to speak of a growing sense of national identity within the Holy Roman Empire of the German Nation around 1500 is far more hazardous: carefully defined, elements of such an identity were visible in southwest Germany, as the venerable debate over the correct assignation of Alsace to Gallia or Germania indicates.

It is perhaps predictable that an economic and social historian is less concerned with abstract and sometimes arid debates over the nature of the Empire as a polity. Yet, as I observe in my original contribution, the economic and commercial marginalization of the Empire in early modern Europe helped defuse what might otherwise have become fierce struggles for hegemony. Here, Wilson's studies of the Thirty Years' War seem not to have attracted much comment. Nor has his reluctance to engage in any depth with radically different approaches to the Empire, such as Peter Blickle's "communalism" thesis, which argues that the Empire's durability, functioning, and legitimation were sustained as much from below as from above. It may well be that Blickle's arguments are too narrowly focused on southern Germany and the Alpine lands to carry conviction (quite apart from the question of their intrinsic coherence). But, as the debate over Peter Wilson's magnum opus commences, there are clearly aspects of the Empire that deserve to be explored further-however exhaustive his treatment appears to be.

\section{Response by Peter H. Wilson (All Souls College, University of Oxford)}

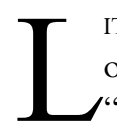

ITERALLY, as I sit down to write, a friend has just sent me the following joke: A professor of history buys a dog and a colleague asks, "Have you thought of a name for the beast?" "Why, certainly," responds the professor, "I was thinking of naming it the Holy Roman Empire." "But why?" asks his bewildered friend. "Well, it's really quite simple," replies the history professor, "You see, the dog is neither holy, nor Roman, nor an 
empire." Somehow, I doubt that the Empire will ever be free of Voltaire's famous quip, first voiced in 1756 when there were still another fifty years to go before Emperor Francis II dissolved it by releasing all imperial vassals from their feudal ties to him as emperor. The passage appears in Voltaire's discussion of the Golden Bull of 1356, in which Emperor Charles IV fixed electoral arrangements to exclude his opponents, and which became one of the Empire's most hallowed constitutional documents. It is interesting that the key sentence was omitted from the 1759 English translation, but that version retained enough of Voltaire's other disparaging remarks for readers to be left in no doubt that he considered the Empire to be without meaning. For him, it had become merely "the empire of Germany," which had lost its other lands, while the "imperial dignity ... conferred no real power," and its politics were only "pompous ceremony"- "Ce corps qui s'appelait et qui s'appelle encore le saint empire romain n'était aucune manière ni saint, ni romain, ni empire."17 Voltaire's quote is certainly the best-known line about the Empire among Anglophone readers, but he was scarcely original in voicing such opinions, even in his own time. Today, Germans are far more likely to know Samuel Pufendorf's characterisation of the Empire in 1667 as a "monstrosity," because it did not fit the established categories used at the time to discuss states and their development. Pufendorf himself drew on earlier critiques, but his work popularized the belief that the Empire had declined from a "regular kingdom" to an "irregular body." 18

Voltaire's quip underscores just how problematic each of the words Holy, Roman, and Empire has become in discussions of the Empire. The suffix "of the German Nation," first added in 1474, has proved still more controversial, because it suggested, as Voltaire argued, that the Empire was simply a German rather than a (Central) European state. The subsequent disagreements over what "Germany" was, or should be, just made matters worse. Protestants and pro-Prussian writers generally condemned the Empire as a failed "nationstate" and as a barrier to national unification. In fact, use of the designation "Holy Roman Empire of the German Nation" sprang from late fifteenth-century disputes with the papacy. It was far more likely to be used by Protestants than by Catholics after 1517, but it rarely appeared in official documents. Despite ceremonial protocol becoming an academic discipline and the subject of numerous learned treatises during the seventeenth century, the Empire actually lacked a formal title and was referred to in varying combinations of Holy, Roman, and Empire, but most usually just as "the Empire." This imprecision has baffled and even infuriated later historians, reinforcing the tendency to criticize and condemn the Empire. As the popularity of Voltaire's quote indicates, it is far easier to say what the Empire was not than to explain what it was, how it worked, and why it mattered.

Addressing these questions was the aim of my book. It led me to write the Empire's history as a European story larger than that of one country or people. It was "holy" in the sense that defense of Christendom, and, more particularly, of the Christian church, legitimated its existence and the emperor's status and imperial pretensions. In more practical terms, the Empire was holy thanks to the significance of clerics and church institutions to

\footnotetext{
${ }^{17}$ See F.M.A. de Voltaire, Essai sur les moeurs et l'esprit des nations et sur les principaux faits de l'histoire depuis Charlemagne jusqu'à Louis XIII, vol. I, ed. René Pomeau (Paris: Garnier, 1963), 683. English translation as An Essay on Universal History, the Manners, and Spirit of Nations from the Reign of Charlemagne to the Age of Lewis XIV, vol. II (London, 1759), chap. 48.

${ }^{18}$ Samuel Pufendorf, Die Verfassung des Deutschen Reiches, ed. H. Denzer (Stuttgart: Reclam, 1994).
} 
its governance, something that lasted into early modernity, and to the continued survival of the "imperial church" (Reichskirche) as a significant structural element until 1802. It was "Roman" in that it claimed continuous direct descent from ancient Rome, and because it incorporated elements of late Roman symbolism and political and legal practices. More fundamentally, it embodied the ideal of a single political order supposedly synonymous with Christendom. And it was this aspect that also made it an empire, in the sense of a universal political order that refused to accept formal limits to its jurisdiction and that legitimated its authority by claiming to uphold law and safeguard peace throughout this singular "civilization."

While the "Holy" and "Roman" elements were primarily symbolic, the imperial aspect profoundly shaped how the Empire was governed. To understand this, we must dispense with the "core-periphery" model that shapes current scholarly discussions of empires and that defines them as governed by an imperial people occupying a clearly defined core territory, while dominating and exploiting various peripheral areas and subject peoples through forms of divide-and-rule. This model is certainly useful in understanding European colonial empires during the nineteenth century, for example. But not all empires have operated like this, and applying this model to the Holy Roman Empire conditions us to look for things that simply were not there-notably, centralized mechanisms of control and resource extraction. The habit of measuring the Empire against a single model of empire, or, for that matter, against a single model of a nation(al) state, is why most interpretations have been so hostile, because the Empire is always going to fall short of these ideals. It was imperial in the sense of constituting a transnational form of governance that behaved as if it were a single civilization, separate and superior to the peoples beyond its deliberately ill-defined frontiers.

I am very grateful to all four reviewers for their thoughtful, considered, and generous comments. That they agree on certain aspects of the book is, of course, pleasing, but that they also differ on others is healthy for debate and thus particularly welcome. Space precludes discussion of every point, so the following response will concentrate on six issues that emerge from all four commentaries - or at least from some of them individually. The first and probably most significant of these is whether it is appropriate to write a history of the Empire spanning the period from Charlemagne's coronation in 800 to Francis II's abdication in 1806. I agree with all four reviewers that the question of continuity and coherence is fundamental to all broader interpretations of the Empire. Are we, in fact, dealing with a single entity across more than a millennium? This question goes to the heart of whether the Empire was anything more than a large kingdom in Central Europe. Charlemagne's coronation certainly did not mark the conscious foundation of an empire intended to last over ten centuries. Neither Charlemagne nor Pope Leo III nor indeed any of the Carolingian elite possessed any such political vision, nor did they work according to any constitutional blueprint. The absence of clear or coherent plans should in itself not detract from what did emerge around 800 from the papacy's alliance with the powerful Frankish king. It would be hard to find examples of any states that were consciously founded before the American republics of the late eighteenth and early nineteenth centuries, and even these emerged more ad hoc than in a planned manner through rebellions against European colonial rule. The absence of a deliberate imperial foundation is therefore not significant in assessing whether the Empire was actually imperial, or whether it continued to exist beyond Charlemagne's death in 814 . 
I have argued that there was a continued sense of a wider imperial realm beyond that year, in which contemporaries recognized individual kingdoms but acted as if these were part of a single political and cultural space that should, ideally, be headed by one king who was crowned emperor. Part of the historiographical problem is that, by 962 , it had become established that whoever was king of what was, by then, generally known as Germany was accepted as the leading candidate to be crowned emperor. The association between the Empire and the German kingdom has, as is widely acknowledged, been subject to anachronistic interpretations that expect emperors to be German state-builders-and that bemoan the fact that they sacrificed their alleged "national duty" in favor of pursuing the chimera of imperial power, especially by launching costly and often abortive campaigns to enforce their authority in Italy. In fact, the imperial title passed between various Frankish kings between 814 and 962 . There were indeed long periods when no king held the title, but each monarch who was crowned emperor claimed to be assuming a preexisting title rather than creating a new one. The same was true for Otto I on his coronation in 962, despite various aspects of the ceremony acknowledging his Saxon rather than Carolingian heritage. The Empire was thus transpersonal from the outset and did not extinguish on the death of individual emperors.

I have also argued that it is legitimate to speak of it as being a single, continuous entity. That is not the same as saying that it was monolithic or unchanging. I agree entirely that it had multiple histories in the sense that its governance and later its constitution were always the subject of discussion and not infrequent disagreement. But this does not mean there is any less reason to write about it as a single history than to do so for France, England, Spain, Russia, or any other country. All European countries have undergone multiple stages of development, while their legitimacy, governance, territory, and identity have all been contested for at least substantial parts of their history. All claim very long histories reaching back generally to the eight to eleventh centuries. It seems odd that few question the scholarly legitimacy of writing a history of, say, France since the Gauls - yet, object to presenting that of the Empire as a single story. Both seem worthwhile enterprises, provided, of course, that they take due account of the discontinuities amid the continuities.

The second important issue concerns the Empire's relationship to nations and national states - a question I attempt to answer in the second part of my book. Both nation-states and national states are generally discussed using some variant of Max Weber's definition of a state as the sovereign monopoly of legitimate power over a given territory. ${ }^{19}$ To conform to this, both are expected to be governed centrally through recognized institutions that enable the state to interact with its inhabitants uniformly and equally. The principle difference between a nation and a national state is the composition of the population, with the expectation that the former is inhabited by a distinct people sharing a common language and culture. The Empire was never a nation-state or even a national state, but it would be wrong to draw too sharp a contrast between it and these political forms in terms of how their histories can be written.

Like institutions, states are indeed collective fictions, as Barbara Stollberg-Rilinger points out, but this also applies to national and especially nation-states, and not just to the Empire. States function because the majority of their inhabitants behave as if the state exists. However, real life pressures, like economic crises, cause people to question their place in society and ask

\footnotetext{
${ }^{19}$ Max Weber, From Max Weber: Essays in Sociology, ed. and trans. H. H. Gerth and C. Wright Mills (New York: Oxford University Press, 1946), 77-128.
} 
whether their political order is working. Such questions challenge the state's continued existence, but the search for explanations is generally expressed as a desire for simple, seemingly quick remedies, rather than in discussions of complex constitutional or legal matters. This is why nationalism currently appears on the rise in Europe, as populists identify immigrants and other domestic targets, as well as supranational organisations like the EU, as scapegoats for problems that are so frightening precisely because they are genuinely beyond the capacity of individual governments to solve. Such populism is not a sign that national identity is growing stronger, but rather that it is under pressure. When pushed, few would be able to agree on what constitutes a specific identity, since this is something always contested and inconsistent. Above all, like the countries with which it is associated, national identity changes over time. What it has meant to feel, say, German or Italian in 2017 is not the same as it did in 1917, let alone in 1933, 1871, 1860, or any other historically significant year one might pick. The key point is that there is no compelling reason to regard the Empire as more "fictional" than any other state, even if its forms of governance, institutional structures, and patterns of identity might differ from now idealized norms.

A third point concerns my decision to structure the book around four broad themes, rather than as a handbook or as a single chronological narrative. As the reviewers rightly point out, the thematic approach has drawbacks, as well as advantages. Any desire to be comprehensive risks writing the Empire's history as a compilation of descriptive encyclopedic entries, as attempted by the early modern "imperial publicists"- - most notably, by Johann Jacob Moser, who produced two very valuable but unwieldy works running to over seventy volumes that tried to cover every institution, note every major event, and list every exception to the innumerable rules. ${ }^{20}$ His desire to fix everything in writing was part of a wider reaction among his contemporaries to the problems of constitutional fuzziness, which Barbara Stollberg-Rilinger explains so well in her comments.

The standard narrative approach allows a reader to see developments over time, and certainly offers scope for more lively storytelling. It also offers opportunities to pause at various points to go into more detail on certain issues - for example, to explain the development of individual institutions or to outline specific conflicts. But there are also significant disadvantages to this approach, especially where the Empire is concerned. It risks repeating the shortcomings of the few other general histories of the Empire, which largely reduce its story to a high-political narrative peopled with heroes and villains, while simultaneously conveying a false sense of linear development that is presented, as already noted, as inevitable decline into irrelevance. I am pleased to see that all four reviewers agree with me in rejecting the standard dualist framework widely used to structure chronological accounts, which charts the Empire's supposedly inexorable disintegration in terms of a struggle between centralizing forces personified by the emperor, and centrifugal elements represented by the princes. It is more helpful to see the Empire and its constitutent territories as coevolving in a relationship that changed but was not invariably conflictual or that always came at the expense of the Empire's political coherence.

How the various elements of the Empire interrelated leads to a fourth point raised by Tom Scott, which concerns the question of whether the late medieval alliances and leagues offered a possible alternative line of political development to that represented by

\footnotetext{
${ }^{20}$ See Mack Walker, Johann Jacob Moser and the Holy Roman Empire of the German Nation (Chapel Hill: University of North Carolina Press, 1981).
} 
the princely territorial state. This is an important issue that, I agree, has generally been underestimated in most discussions of the Empire. Part of the reason why I eschewed a conventional political chronology was that this approach naturally preferences the doings of the monarchical and aristocratic elite, and often leaves the impression that the Empire had no relevance for the lives of its inhabitants. The fourth part of my book attempts to anchor the Empire's history in the broader social, economic, cultural, legal, and, indeed, also political history of its more humble inhabitants. I have tried to show how the Empire's evolution into a corporate legal and constitutional order by early modernity was rooted in more general social and economic developments, which means that we cannot understand its structure and governance without also including the relationship between its political elite and the many varied forms of community that were embedded in the complex web of jurisdictions and legal rights.

This complex socio-legal order combined vertical elements of command, subordination, and reciprocity with horizontal, associative elements. These two forms were in tension with one another; their relationship changed and was not uniform across all social and political levels, or in each part of the Empire. Collectively, however, they were a fundamental defining feature of the late medieval and early modern Empire. Their existence created numerous opportunities for leagues and associations that could be organized among peers-such as leagues composed only of princes, or only of peasants or commoners. They could also combine different social and political Estates, like the famous Swabian League of 1488-1534. That organization also demonstrated that they could be organized on a regional basis. But equally cross-regional associations were also possible. The multiplicity of these forms of association was an important indicator of the vibrancy of the Empire's political culture at this point. The key point I try to make in Chapter 11 of my book is that these associative forms were integral to the Empire, not alternatives to it. Leagues were largely political "dead ends," however, because it became clear by about 1550 that political integration within the Empire, especially through possession of the quality of imperial Estate (Reichsstand), offered better security for autonomy, rights, and status. Many forms of association withered as their members preferred to advance their goals through participation in the new imperial institutions that consolidated during the later fifteenth and sixteenth centuries. The demise of organizations like the Hanseatic League was not necessarily a "good" thing for the Empire. I agree entirely with Barbara Stollberg-Rilinger's argument that the Empire's political and especially constitutional options gradually narrowed during the seventeenth and eighteenth centuries. As she has written elegantly elsewhere, a major factor in this was the substitution of a political culture based on personal presence for one reliant on communication through writing. ${ }^{21}$

These considerations prompt the further question of how we should interpret the Empire. I entirely concur with the reviewers that it is important not to overestimate harmony or paint a rosy picture of consensus politics. Political consensus was often fragile, especially in the earlier Middle Ages. It could also be stifling, and was certainly often deeply frustrating for those who experienced it. For example, many living in the sixteenth century regarded the legal parity of confessions enshrined in the Peace of Augsburg of 1555 as a license to serve the devil. Much of the Empire's history was indeed very violent, as Len Scales rightly points out. I have tried to convey something of the furor teutonicus, and the book includes an image of Archbishop

\footnotetext{
${ }^{21}$ Barbara Stollberg-Rilinger, The Emperor's Old Clothes: Constitutional History and the Symbolic Language of the Holy Roman Empire, trans. Thomas Dunlop (New York: Berghahn, 2015).
} 
Baldwin of Trier splitting the head of an Orsini opponent during Henry VII's coronation journey of 1312. Like the question of coherence, the level of violence and instability in the Empire needs to be set into context. The customary, overly negative interpretation rests on the expectation that things were generally bad in the Empire, whereas similar events or phenomena in other countries are regarded as exceptional—or at least treated more benevolently. All major European states have had a long history of metropolitan violence against refractory regions or peoples. British history, for example, includes Edward I, known as the Hammer of the Scots; the "Bloody Assizes" of "Hanging Judge" Jeffries in the West Country, after the failed Monmouth Rebellion of 1685; "Butcher" Cumberland's campaign of 1746 against the Jacobites and the subsequent Highland Clearances—not to mention the English record in Ireland.

We certainly need to remember the failings of imperial institutions. For example, as Tom Scott notes, the imperial courts were unable to solve the growing problems of indebtedness in the smaller principalities and imperial cities. Intervention by imperial institutions often appeared successful, leading to stabilized finances, rewritten civic constitution, and occasionally even the deposition of wayward princes. However, as I show in Chapter 12, intervention almost invariably addressed symptoms rather than causes. A core argument of the book is that the Empire was anchored in a corporate social order increasingly challenged by accelerating economic change and demographic growth after the 1730s. Again, such pressures were hardly unique to the Empire, but it is questionable whether the existing framework could have coped with them. In this I differ from Joachim Whaley's more positive interpretation of the early modern Empire. ${ }^{22}$ The Empire was certainly not on life support by the late eighteenth century, but it is nonetheless doubtful that it could have adapted sufficiently to surmount these underlying pressures, even if it had not been challenged militarily by France after 1792.

The final point is raised by Len Scales, who compares my work to a late medieval or early modern Reformschrift in that it uses the Empire's history to comment on developments in today's Europe. While it is primarily a history book, it was also written with an eye to the present, including the future of the EU after the United Kingdom's departure through Brexit - something that shifted from being what appeared an unlikely possibility to become a harsh reality between the submission of the typescript and the publication of the paperback edition. The final chapter does address how the Empire's history has been used to comment on the EU past, present, and future, but its main purpose is to prompt more general reflections on the relationship among individual, state, and society. The national state as conceived in nineteenth-century Europe and imposed largely by force on the rest of the world no longer fits global realities. Again, I believe that the rise of populism is a reaction to this through attempts, such as Brexit, to reassert the nation(al) state. However, the forces of globalization, technological change, and other long-term developments cannot be rolled back, however much people may desire that. The book is thus not directly a call for a better Europe or EU, and it certainly does not intend to present the Empire as a blueprint for a new Europe — as a few German historians, such as Peter-Claus Hartmannn, have attempted since the early 1990s. Rather, if the book has an explicit message, it is to encourage greater recognition of the fact that complex problems, such as those certainly faced by Europe today, defy simple answers, and that meaningful change will take time and require a willingness to compromise.

\footnotetext{
${ }^{22}$ Joachim Whaley, Germany and the Holy Roman Empire, 1495-1806, 2 vols. (Oxford: Oxford University Press, 2012).
} 